\title{
Molecular Characteristic of Dengue Virus against its Outbreak response of Red Sea State, Eastern Sudan - 2020
}

\author{
Israa Abbas ${ }^{1}$, Anass Abbas ${ }^{2}$ (D), Manar Shalabi ${ }^{2}$, Hatem Mohamed ${ }^{3}$ (D), Abdel-Moniem M. Arjabey ${ }^{4}$, Asaad M. A. Babker ${ }^{5 *}$ (D), \\ Al Fadhil A. Omer ${ }^{1}$ \\ ${ }^{1}$ Department of Medical Microbiology, Faculty of Medical Laboratory Science, Alneelain University, Khartoum, Sudan; \\ ${ }^{2}$ Department of Clinical Laboratory Sciences, College of Applied Medical Sciences, Jouf University, Sakakah, Saudi Arabia; \\ ${ }^{3}$ Department of Medical Education, College of Medicine, Najran University, Najran, Saudi Arabia; ${ }^{4}$ Department of Clinical \\ Chemistry, Medical Laboratory Science Program, Portsudan Ahlia College, Portsudan, Sudan; ${ }^{5}$ Department of Medical \\ Laboratory Sciences, College of Health Sciences, Gulf Medical University, Ajman, United Arab Emirates
}

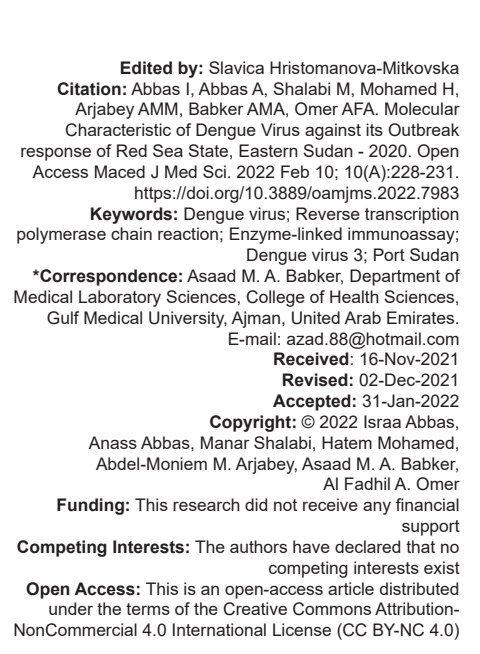

\section{Abstract}

BACKGROUND: Dengue fever is ranked by the World Health Organization as the most critical mosquito-borne vira disease, globally. More than $40 \%$ of the world's population, in more than 100 countries are at risk of dengue infection.

AIM: The objective of this study was to determine the prevalence of dengue virus (DENV) genotypes and serotypes during disease outbreak 2020 in Port Sudan State, eastern Sudan.

METHODS: This study was a descriptive cross-sectional study conducted at Eastern Sudan (Port Sudan state) Three hundred and eighty serum samples were collected from febrile patients including any individual aged $\geq 5$ years old and excluded all patients suffering from Tuberculosis, rheumatoid arthritis was excluded and those who have a history of travailing to an endemic area within the past 2 weeks. Reverse transcription polymerase chain reaction (RT-PCR) assays were used to amplify a fragment of the viral polyprotein gene. The PCR products of the amplified viral polyprotein gene were purified, and partial sequences were generated and used to confirm the specificity of DENV sequences and to identify the virus serotype. Data analysis was performed using Statistical Package for Social Sciences (SPSS, version 23.0)

RESULTS: Infection was confirmed in $27.9 \%$ in 106 samples out of 380 sampled sera, using DENVenzyme-linked immunoassay assay. The detection of DENV RNA was made possible using group-specific RT-PCR assay. The virus was DENV serotype 3 (DENV-3) serotype-specific RT-PCR assay.

CONCLUSION: The findings of this study indicate that DENV-3 of DENV is circulating and we did not detected DEN1,2 and DEN-4 in outbreak in eastern Sudan during the year 2020.

\section{Introduction}

Dengue is a mosquito-borne viral disease of the $21^{\text {st }}$ Century and is considered as an important threat to public health and ends up in significant socio-economic encumbrance in an oversized range of tropical, semi tropic, and temperate regions of the world [1], [2]. Approximately, around 100 million dengue cases are reported and over 390 million people have a probability of infection worldwide every year [3]. The causal agency of dengue virus (DENV) belongs to family of virus known as Flaviviridae and genus Flavivirus, four antis genetically distinct serotype is (DENV1, DENV2, DENV3, DENV4) and five recognized serotypes (DENV 5) characterized by neutralization assays [4], [5]. These viruses are transferred by female Aedes (Ae.) mosquito (Diptera: Culicidae) particularly. Aegypti (Linnaeus) and to a lesser extent Aedes albopictus (Skuse) that benefits from human blood. These mosquitos gain access to human blood indoors and outdoors throughout dawn to nightfall and may be found in tropical and subtropical regions, significantly dominant in urban surroundings and spreading out to rural areas. These mosquitoes may also transmit chikungunya, Zika infection, and yellow fever [6], [7]. Dengue is complex and complicated disease with clinical sickness, clinically classified as mild to severe including undifferentiated fever, dengue fever (DF), dengue hemorrhagic fever (DHF), DF shock syndrome (DSS), and extended DF syndrome [1]. DF may be a terrible, flu-like disease that distresses babies, young kids, adults and rarely causes death. DF should be doubted with high fever $\left(40^{\circ} \mathrm{C}\right)$ followed by these signs: severe headache, joint and muscle discomfort, swollen glands nausea, pain behind the eyes, and vomiting. When 4-10 days' bite from associate infected mosquito symptoms usually appeared and lasted for 2-7 days. However, DHF and DSS are a lot of severe and presumably deadly forms with symptoms such as plasma leaking, respiratory distress, and severe abdominal pain [1], [8]. The lack of rapid and accurate diagnosis and unavailability of detailed analysis of 
DENV outbreak in most African countries have resulted in limited information related to the true disease burden and economic impact of the disease Investigations into DENV incidence in Sudan have produced variable results, presumably due to geographic, temporal, and methodological differences [9]. In Sudan, very little information is available about the circulating serotypes and associated genotypes. The serological surveys constitute the bulk of the research conducted on the epidemiology of the disease The present study was conducted to determine the prevalence of DENV genotypes and serotypes during disease outbreak 2020 in Port Sudan State, Eastern Sudan.

\section{Methods}

This cross-sectional study was carried out to determine DENV antibodies status in Red Sea state, DENV antibody test was done for each sample. The blood samples were collected and tested for (DENV) immunoglobulin $M$ by using enzyme-linked immunoassay (ELISA). 380 serum samples were collected during the outbreak from residents of Port Sudan State. After the patient's consent form was signed three $\mathrm{ml}$ of venous blood was collected from patients in a plain container and allowed to clot at room temperature. Then, the samples were centrifuged, and serum was separated in a sterile container and stored at $-20^{\circ} \mathrm{C}$ until analysis. ELISA was used to detect DENV in acute-phase sera sampled during the disease outbreak [10]. Reverse transcription-polymerase chain reaction (RT-PCR) assays were used to amplify a fragment of the viral polyprotein gene. The PCR products of the viral polyprotein gene were purified, and partial sequences were generated and used to confirm the specificity of DENV sequences and to identify the virus serotype. Data analysis was performed using Statistical Package for Social Sciences (SPSS, version 23.0) The statistical analysis of data was done using mean, standard deviation, the result was presented in form of tables and figures. A p-value and p-value for all study results of $<0.05$ were considered significant for all study results.

\section{DENV detection}

Virus detection and identification were almost exclusively based on detection of DENV by ELISA assay and identification of the viral genome by conventional RT-PCR amplification assay.

\section{Viral nucleic acid extraction}

The QIAamp extraction kit (QIAamp, Hamburg, Germany) was used to extract viral nucleic acids.
RNAs were extracted from infected patient sera as per manufacturer's instructions We quantify the samples to make sure that they contain adequate RNA before application of RT-PCR and subsequent sequencing. RNA extracts were then kept at $-20^{\circ} \mathrm{C}$ until used for PCR amplification. Five $\mu$ of nucleic acid was used for RT-PCR amplification.

\section{Serotype-specific RT-PCR assay for identification DENV}

The semi-nested serotype-specific RT-PCR assay for identification DENV RNA was performed using the same forward primer D1 and an internal reverse primer T3 to amplify a 290- bp PCR product of the same CprM region of the viral polyprotein gene. The thermal cycling profiles for the serotype-specific RT-PCR assay were performed basically as described by Chien et al. [11]. Details of the universal primers employed for amplification of DENV serogroup and serotype-specific PCR products are summarized in (Table 1).

Table 1: Sequence of primers for different serotypes of dengue virus

\begin{tabular}{lll}
\hline Primer & Sequence & PCR product \\
\hline D1 & 5'-TCAATATGCTGAAACGCGCGAGAAACCG-3' & 511bp \\
D2 & 5'-TTGCACCAACAGTCAATGTCTTCAGGTTC-3' & \\
TS1 & 5'-CGTCTCAGTGATCCGGGGG-3' & 482 (DI and TS1) DENV-1 \\
TS2 & 5'-CGCCACAAGGGCCATGAACAG-3' & 119 (DI and TS2) DENV-2 \\
TS3 & 5'-TAACATCATCATGAGACAGAGC-3' & 290 (DI and TS3) DENV-3 \\
TS4 & 5'-CTCTGTTGTCTTAAACAAGAGA-3' & 392 (DI and TS4) DENV-4 \\
\hline DENV: Dengue virus. &
\end{tabular}

\section{Phylogenetic analysis}

The sequences were aligned using Molecular Evolutionary Genetics Analysis software version 7.0. The phylogenetic tree was constructed using the Maximum likelihood statistical method based on the Tamura-Nei model [12]. The GenBank accession numbers, the country of origin and the date of isolation were given for each virus isolate when available. Bootstrap analysis of 1000 replicates was applied, and values were given at relevant nodes of the constructed tree.

\section{Results and Discussion}

Infection was confirmed in $27.9 \%$ in 106 samples out of 380 sampled sera, Using DENVELISA assay. The detection of DENV RNA was made possible using group-specific RT-PCR assay. The virus was serotyped as DENV serotype 3 (DENV3) using DENV serotype-specific RT-PCR assay. DENV transmission among the human population in Sudan was first recognized in 1986 when an outbreak of the disease occurred in the Red Sea State, eastern Sudan [13]. Currently, DENV is spreading widely to 
the western and central Sudan, but the eastern part of the country is endemic with the disease [14], [15], [16]. There are few studies conducted among molecular characterization of DENV. Ina previous report, DENV-2 was reported as an etiological agent of a disease outbreak in Kassala State, 2017. Phylogenetic analysis revealed that the isolated virus sequences belong to the cosmopolitan genotype of DENV-2 [17]. DENV-1 and DENV-3 have been reported in the Red Sea State and in the Darfur region of Western Sudan but no information is available about the molecular characterization of the isolated viruses. Our findings agree with study conducted by Mawahib et al., conducted during outbreak in Eastern Sudan, 2019 and they confirmed that genotype III of DENV-3 was associated with the disease outbreak in eastern Sudan, 2019 [18]. However, in the present study, DENV-3 (27.9\%) was found to be the most prevalent serotype that causes DF and agree with many reports out of Sudan. There are many researches also conducted over the world and concluded that the DENV-3 was the leading serotype in Dehli, India, and Pakistan [19]. Furthermore, some reports showed that the DENV-1, DENV-2, and DENV-3 have been the predominant serotypes of DENV in the Middle East, particularly Saudi Arabia and Yemen [20]. Furthermore, our finding, similar to another retrospective study undertaken to investigate the circulating DENV serotypes and genotypes in India in 2018, reported that the DENV-3 was more common in Western and Northern India. DENV-3 emerged as the dominant serotype in Maharashtra in 2017, and this continued in 2018 [21]. During the current study, we did not detect DEN-1, 2 and DEN-4 in outbreak in eastern Sudan during the year 2020, the small number of samples tested from in the current study may be one of the reasons for the lack of detection of other types.

\section{Conclusion}

The findings of this study indicate that DENV-3 was circulating, and we did not detect DEN-1, 2 and DEN-4 in outbreak in eastern Sudan during the year 2020. Further studies are needed to on co-circulation of multiple DENV serotypes and associated genotypes in this area of endemicity would be necessary to identify which factor or factors are responsible for the DENV outbreaks in Port-Sudan.

\section{Acknowledgment}

The authors are grateful for all patients and volunteers who agreed to participate in this study. Also special thanks to the Ministry of health, Red sea state, Sudan.

\section{Ethical Consideration}

Approval from Al-Neelain University, Khartoum, Sudan and Red sea state ministry of health research department.

\section{References}

1. Guzman MG, Kouri G. Dengue: An update. Lancet Infect Dis. 2002;2(1):33-42. https://doi.org/10.1016/ s1473-3099(01)00171-2

PMid:11892494

2. Gubler DJ. Dengue, urbanization and globalization: The unholy trinity of the 21(st) century. Trop Med Health. 2011;39(4):3-11. https://doi.org/10.2149/tmh.2011-S05

PMid:22500131

3. Bhatt S, Gething PW, Brady OJ, Messina JP, Farlow AW, Moyes CL, et al. The global distribution and burden of dengue. Nature. 2103;496(7446):504-7. https://doi.org/10.1038/ nature 12060

\section{PMid:23563266}

4. Burke DS, Monath TP. Flavivirus. In: Knipe DM, Howley PM, editors. Fields Virology. $4^{\text {th }}$ ed., Vol. 1. Philadelphia, PA: Lippincott Williams and Wilkins; 2001. p. 1043-126.

5. Drumond BP, Mondini A, Schmidt DJ, Bronzoni RV, Bosch I, Nogueira ML. Circulation of different lineages of dengue virus 2, genotype American/Asian in Brazil: Dynamics and molecular and phylogenetic characterization. PLoS One. 2013;8(3):e59422. https://doi.org/10.1371/journal.pone.0059422

PMid:23533624

6. Mustafa MS, Rasotgi V, Jain S, Gupta V. Discovery of fifth serotype of dengue virus (DENV-5): A new public health dilemma in dengue control. Med J Armed Forces India. 2015;71(1):67-70. https://doi.org/10.1016/j.mjafi.2014.09.011 PMid:25609867

7. Brady OJ, Golding N, Pigott DM, Kraemer MU, Messina JP, Reiner RC, et al. Global temperature constraints on Aedes aegypti and Ae. albopictus persistence and competence for dengue virus transmission. Parasit Vectors. 2014;7:338. https:// doi.org/10.1186/1756-3305-7-338

PMid:25052008

8. WHO. Regional Office for South-East Asia. Comprehensive Guidelines for Prevention and Control of Dengue and Dengue Haemorrhagic Fever, Revised and Expanded Edition. New Delhi: World Health Organization South East Asia Regional Office; 2011.

9. Elduma AH, LaBeaud AD, Plante JA, Plante KS, Ahmed A. High seroprevalence of dengue virus infection in Sudan: Systematic review and meta-analysis. Trop Med Infect Dis. 2020;5(3):120. https://doi.org/10.3390/tropicalmed5030120 PMid:32708492

10. Abbas I, Shalabi MG, Abbas AM, Mohamed H, Babker AM, Omer AF. Sero-prevalence of dengue fever virus antibodies 
in red sea state, Sudan-a cross-sectional study. J Pharm Res Int. 2021;33(47A):506-10. https://doi.org/10.9734/jpri/2021/ v33i47A33040

11. Chien LJ, Liao TL, Shu PY, Huang JH, Gubler DJ, Chang GJ. Development of real-time reverse transcriptase PCR assays to detect and serotype dengue viruses. J Clin Microbiol. 2006;44(4):1295-304. https://doi.org/10.1128/ JCM.44.4.1295-1304.2006

PMid:16597854

12. Konongoi L, Ofula V, Nyunja A, Owaka S, Koka H, Makio A, et al. Detection of dengue virus serotypes 1,2 and 3 in selected regions of Kenya: 2011-2014. Virol J. 2016;13(1):182.

13. Ahmed A, Dietrich I, LaBeaud AD, Lindsay SW, Musa A, Weaver SC. Risks and challenges of arboviral diseases in Sudan: The urgent need for actions. Viruses. 2020;12(1):81. https://doi.org/10.3390/v12010081 PMid:31936607

14. Soghaier MA, Mahmood SF, Pasha O, Azam SI, Karsani MM, Elmangory MM, et al. Factors associated with dengue fever IgG sero-prevalence in South Kordofan state, sudan, in 2012: Reporting prevalence ratios. J Infect Public Health. 2014;7(1):54-61. https://doi.org/10.1016/j.jiph.2013.07.008 PMid:24210245

15. Ahmed A, Ali Y, Elmagboul B, Mohamed O, Elduma A, Bashab H, et al. Dengue fever in the Darfur area, Western Sudan. Emerg Infect Dis. 2019;25(11):2126. https://doi.org/10.3201/ eid2511.181766

PMid:31625864

16. Ahmed A, Elduma A, Magboul B, Higazi T, Ali Y. The first outbreak of dengue fever in Greater Darfur, Western Sudan.
Trop Med Infect Dis. 2019;4(1):43. https://doi.org/10.3390/ tropicalmed4010043

\section{PMid:30823624}

17. Hamid Z, Hamid T, Alsedig K, Abdallah T, Elaagip A, Ahmed A, et al. Molecular investigation of dengue virus serotype 2 circulation in Kassala state, Sudan. Jpn J Infect Dis. 2019;72(1):58-61. https://doi.org/10.7883/yoken.JJID.2018.267 PMid:30270247

18. Eldigail MH, Abubaker HA, Khalid FA, Abdallah TM, Musa $\mathrm{HH}$, Ahmed ME, et al. Association of genotype III of dengue virus serotype 3 with disease outbreak in Eastern Sudan, 2019. Viro J. 2020;17(1):118. https://doi.org/10.1186/s12985-020-01389-9 PMid:32731875

19. Kashif M, Afzal M, Zeshan B, Javed H, Batool S, Mazhar M Molecular and haematological analysis of dengue virus-3 among children in Lahore, Pakistan. Jundishapur J Microbiol. 2021;14(1):e109512. https://doi.org/10.5812/jjm.109512

20. Organji SR, Abulreesh HH, Osman GE. Circulation of dengue virus serotypes in the city of Makkah, Saudi Arabia, as determined by reverse transcription polymerase chain reaction. Can J Infect Dis Med Microbiol. 2017;2017:1646701. https://doi. org/10.1155/2017/1646701 PMid:28298933

21. Alagarasu K, Patil JA, Kakade MB, More AM, Yogesh B, Newase $P$, et al. Serotype and genotype diversity of dengue viruses circulating in India: A Multi-Centre retrospective study involving the virus research diagnostic laboratory network in 2018. Int J Infect Dis. 2021;111:242-52. https://doi.org/10.1016/j. ijid.2021.08.045

PMid:34428547 